\title{
Factors Affecting Customer Satisfaction in the Internet Service Industry (Exploratory Study of Internet Service Providers in Erbil - Kurdistan Region)
}

\author{
Bahzad Taher Salim ${ }^{1 *}$, Sirwan Latif Haji ${ }^{2}$, Rizgar Saed Hussein ${ }^{3}$ \\ ${ }^{1}$ Department of Applied Economics, PhD Innovation Management, RUDN University, Moscow, Russia, ${ }^{2}$ Department of Business Management, \\ Erbil Polytechnic University, Erbil, Iraqi Kurdistan Region, ${ }^{3}$ Department of Business Management, Soran University, Diana, Iraq Kurdistan Region
}

\section{${ }^{*}$ Corresponding author: Bahzad Taher Salim, PhD Innovation Management, RUDN University, Moscow, Russia. Mobile: 7504484537. E-mail: behzad82h@hotmail. com}

Received: 01 March 2018

Accepted: 12 September 2018

Published: 30 June 2019

DOI

10.25156/ptj.v9n1y2019.

pp50-63

\section{A B S TR A C T}

The term "customer satisfaction" is a basic marketing expression constructed in the past three decades. In the past, it was an unpopular and unaccepted concept, as the aim of companies was to gain new customers rather than retain the existing ones. However, companies realized and understood the significance of customer satisfaction (especially service producing companies) and have adopted it as the highest priority of their operational goals in the present decade. This study aims to examine overall customer satisfaction with the internet service in the Kurdistan Region of Iraq, factors affecting satisfaction and the relationship between satisfaction and demographics. Data were collected from 400 customers who were randomly selected. The results gained in this study revealed that $81.5 \%$ of respondents were satisfied. The combination of network quality, billing, speed, and customer support (internet services attributes) indicated a relationship with satisfaction, while age, education, gender, and employment variables indicated no relationship. Results show that the rate of satisfaction is high but the internet service companies can improve their services to reach the level of developed countries.

Keywords: Chi-square; Customer satisfaction; Erbil; Internet services

\section{INTRODUCTION}

The previous regime in Iraq rejected the development of any kind of communication technology in the Kurdistan area; after the Kurdish uprising in 1991, they cutoff all means of communication between Kurdistan and other parts of Iraq; consequently, Kurdistan became an isolated area of the country. Iraqi government also do not had acceptable internet services and not for all the people. The Kurdistan Regional Government (KRG) was unable to develop the communication sector because of imposed sanctions and the isolation by the regime until 2003 when coalition forces invaded Iraq. The KRG then began to develop communication technology; the result was reconnection to other parts of the area and the world. At the same time, the KRG started to invest in the oil industry and to construct an infrastructure for the industry in the region (Khayyat and Heshmati, 2012).

The challenge for business today is to move from product orientation to customer focus. This is becoming more difficult because now customers are increasingly sophisticated, educated, and well informed. They have high expectations of the service they want to receive. They want greater choice and will not be "sold to" or manipulated.
Therefore, nowadays, customers are willing to be treated as an individual. They want to be valued and to feel their custom important. Service organizations constantly strive for a higher level of customer services (Cook, 2002).

Customer satisfaction is defined as an "evaluation of the perceived discrepancy between prior expectations and the actual performance of the product" (Oliver, 1999). The satisfaction of customers with products and services of a company is considered as most important factor leading toward competitiveness and success (Hennig-Thurau and Klee, 1997). Customer satisfaction is actually how customer evaluates the ongoing performance (Gustafsson et al., 2005). According to Kim et al. (2004), customer satisfaction is customer's reaction to the state of satisfaction, and customer's judgment of satisfaction level. Customer satisfaction is very important in today's business world as according to Deng et al., 2009, the ability of a service provider to create high degree of satisfaction is crucial for product differentiation and developing strong relationship with customers. Customer satisfaction makes the customers loyal to one telecommunication service provider. Previous researchers have found that satisfaction of the customers can help the brands to build long and profitable relationships with their customers (Eshghi et al., 2007). 
Total care of the customer can only be achieved when the need of the internal as well as external customers is considered. A good customer service meet customers' expectation which is influenced by such factors as competitive pricing, employees courtesy and behavior, good value, and service quality. However, a good employee tries with heart and mind to ensure the best possible service for the customer.

\section{Previous Studies}

Jalula, 2011, states that there is a remarkable relationship between the development of information and communication technology and growing business transactions and customer demands; currently, technology is one of the most significant factors, working as a dynamic for changing the general business environment. It also has a great role in bringing new products, services, marketing opportunities, as well as developing information systems that are business oriented and support management processes such as planning, controlling, and coordination.

Another study, conducted under the title "internet-based interactions," the results of which show the growth of delivery of services, products, and information; the results also reveal that e-commerce applications have multiplied when the rate of internet users' access and use of the internet increased. Another advantage of the internet is online retail sites which are at the forefront of developing applications that support and offer customers efficient search opportunities through products, service options, procuring product information, making purchases and tracking orders, some examples of which are Dell.com for computer online retailing, Amazon.com for online book purchases, Landsend.com for clothing retail, and Travelocity.com for travel services. Products and services are available in digital format in the markets and can be transferred through information-based channels (Ju et al., 2016).

Clearly, the internet played an important role in the revolution and in changing the business landscape which became a remarkable resource for connection to customers. The role of the internet in changing the business world is not only restricted to business transactions where companies do business and consumers buy products but it also creates new business channels through the delivery of a link from manufacturers to retailers and consumers (Janda et al., 2002).

Customer satisfaction is an important factor in business which can be achieved through customer perception and psychological reaction of the consumer experience. In the late 1980 s, a theory was proposed called the "expectation disconfirmation theory," according to which, intensity (size) and direction (positive/negative) of the gap (disconfirmation) between expectation and comprehended performance will define and reveal customer satisfaction (Khalifa and Liu, 2016).

In their research, Roy, 2013; Sanchez-Franco et al., 2009, evaluated customer satisfaction between male and female youngsters to designate the variable differences. For data analysis, they used one-way ANOVA. The results revealed that there are considerable differences between males and females, where the male samples considered themselves to be more experienced in comparison to the female samples. The aims of the study were to hypothesize about the influence of online methods of communication on customer satisfaction and loyalty, as well as the relationship between satisfaction and loyalty.

Gerpottet al.,2001, investigated customer satisfaction, loyalty and retention in the German mobile telecommunications among 684 respondents and reported that customer retention cannot be equated with customer loyalty and/ or customer satisfaction, rather a two-stage causal link can be assumed in which customer satisfaction drives customer loyalty which, in turn, has impacts on customer retention. However, these three factors are important for superior economic success among telecommunication service providers.

Kim et al., 2004, investigated the effects of customer satisfaction and switching barrier on customer loyalty among 350 respondents in Korea and reported that call quality, value-added services and customer support have a significant impact on customer satisfaction. Thus, to maximize customer satisfaction, focus should be on service quality and customer-oriented services. Switching barrier, on the other hand, is affected by switching costs (e.g., loss cost, move-in cost, and interpersonal relationships) and was revealed to have an adjustment effect on customer satisfaction and customer loyalty. According to Turel and Serenko, 2006, that investigated customer satisfaction with mobiles services in Canada and reported that perceived quality and perceived value are the key factors influencing satisfaction with mobile services. Customer care is reported to be negatively related to customer satisfaction, which means that a more satisfied customer is less prone to complain.

\section{Research Problem}

Customer satisfaction is very important because that would create sense of belongingness, emotional binding, and brand loyalty among customers. Satisfaction was operationalized as "if needs or demands of customers are fulfilled through particular product or service" or if customer feels that he gets the desired benefits from the 
goods or services for which they have paid to a particular firm. The main motive of this study was to check how factors of customer services and price fairness add value toward creating satisfied customers or otherwise. Customer service is the most powerful stimulant of brand loyalty.

The problems of this research are: Identifying factors that influence customer satisfaction in Kurdistan Region and Erbil city as a niche are there different opinions on the nature of services provided by these companies? Are internet service companies in Erbil to diagnose the obstacles to providing these services? Do internet service companies in Erbil measure customers' satisfaction with their services periodically and identify the causes of dissatisfaction and work to address them?

\section{Research Importance and Objectives}

Customer satisfaction has been a major goal for business organizations for many years and that loyal customers contribute to the company's profitability by spending more on the company's products and services. Customerorientated companies will strive to satisfy their customers. This forms one of the bases for the establishment of lasting and profitable relations with key customers. Most companies strive to establish high levels of customer satisfaction. It can, therefore, be assumed that the establishment and maintenance of acceptable customer satisfaction levels should be the aim of any company that wants to be profitable and survive in a competitive business environment.

The main purpose of this study is to recognize and quantify the impact of factors that drives customer satisfaction in internet services as well as to determine the relationship between the demographic variables and the degree of customer satisfaction. Thus, we can summaries the research objectives in some points: (a) Diagnose the obstacles of providing internet services to customers in Erbil city, (b) measure the satisfaction of customers with the services of the companies that provide internet service in Erbil, and (c) identifying the reasons for dissatisfaction with these services.

\section{Research Questions}

The questions of this research that we want to investigate are as follow:

1. What is the overall customer satisfaction of the internet customer satisfaction industry in Erbil city?

2. What are the factors influencing customer satisfaction?

3. What is the link between certain demographic variables (age, gender, type of employment, and location) and customer satisfaction in the Erbil internet service industry?

\section{LITERATURE REVIEW}

\section{Service \\ The concept of service}

In today's economy, service is everywhere and it has increased in importance over the last decade with the advent competition. Intense competition, encouraged by deregulation in both the financial and professional markets as well as the application of modern technology, has fuelled this growth. Kotler and Keller, 2009, define services "service is any act and performance that one party can offer to another that is essentially intangible and does not result in the ownership of anything." Fitzsimmons and Fitzsimons, 2008, defines "a service is a time perishable, intangible experience performed for a customer acting in the role of coproducer."

\section{Services Classification}

Kotler and Keller, 2009, mentioned that the service component can be distinguished to five categories by offerings, first is pure tangible good with no service accompanying with the goods - such as toothpaste, salt. The second offering is tangible good accompanied by one or more services. More technologically advanced product is categorized here-cell phone, crucial car, etc. The third consist of equal parts of goods and services, such as restaurant. The fourth consist mainly with major services, additional services and supported by the goodslike airline travel package and finally the pure services offering babysitting.

Lahtinen and Isoviita, 1994, described that services can be classified in different ways but mainly they highlight in three main categories, (a) standard versus customized serviceslike telephone company and the newspaper provided the same services to every customer but fitness club, bank, restaurant, insurance companies provide more tailored services to the customer according to their needs, and (b) consumer versus industrial service - the service that is given to final consumer is the consumer service and services that given to the customer to shape their own final product is industrial services. A bank provides both industrial and consumer services (c) personal versus non personal service - the basis is whether personal contacts are needed in the service transaction. The examples - medical treatment, hair cut need direct contact with customers, on the other hand, security companies, power plants, auditing companies provide services without personal contacts with customer.

\section{Services characteristics}

Kasper et al., 2006, defined services characteristics can be referred as the five "I" of services. The five "I" are intangibility, inseparability, inconsistency, inventory, and inability of own. 
Intangibility - the degree of (in) tangibility - as services is an activity or an experience not a thing; thus, normally, it is not like tangible goods. Although many services cannot be provided without tangibles - for example, transportation services need truck, planes cars or any sort of vehicles.

Inseparability - a degree of simultaneous production and consumption - generally the consumer of the services will have to participate in the production of that service. Haircut, doctor's treatment, theater performance, even in internet services, require consumer participation.

Inconsistency - a degree of heterogeneity - in services process, the service provider and customer are influenced by the service environment to create the right atmosphere. Service widely varied at this point because it depends on who provides them, when and where, to whom.

Inventory - a degree of perishability - service is hard to store if the service is more intangible or in other words, perish ability increases. This characteristic also creates problem to match the demand-supply problem of service.

Inability to own-a degree of lack of ownership-referring from the service definition, the service does not always result in the transfer of title or ownership. Services are deeds and performances, thus when a customer rents a car he/she got the rights to have some facilities and not own the car (Kasper et al., 2006).

\section{The elements of good service}

In customer-oriented business customer plays an important role as they are the main parts who buy the services and if they like the service than become a repeat customer and also bring new customer. Thus, service should be provided in the way of service package, from the customers' point of view, of good quality. Figure-1 shows that good service includes four elements, providing service, service package, service quality, and service culture. If any of these elements break the service system; the total service will be incomplete (Lahtinen and Isoviita, 1994).

Providing service: When service provided to the customer three main elements participate in the service production, (1) service environment, (2) contact personnel, and (3) other customers. Providing service is actually a series of activity of these three elements. In the service proving activity some customer participates actively by sharing suggestion or giving positive and negative feedback to the personnel; other remains passive like let the personnel do their own job. Thus, each customer needs to be served differently but should be served with equal respect. Contact personnel may be distinguished in two grouped, both

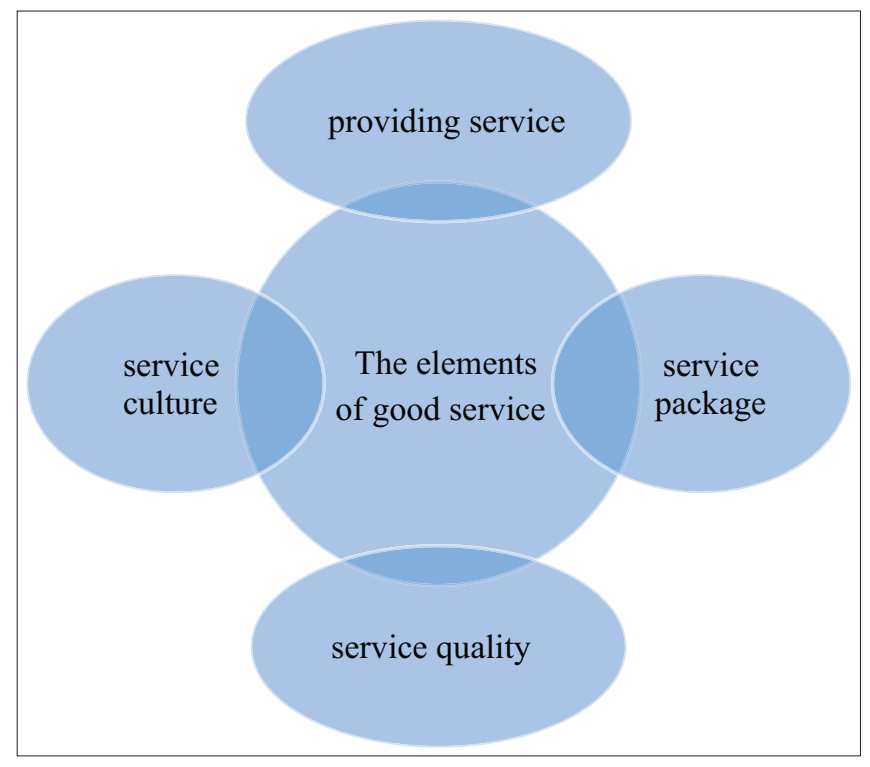

Figure 1: Elements of good service system - a basis for good service

Source: Lahtinen and Isoviita (1994) customer relationship marketing. KP paino, Kokkola, Avaintulos OY

continuous and direct contact with the customer or seldom and infrequently in contact with the customer.

\section{Service package}

Taking consideration into customers service markets different service package that design to match different customer wants and needs. These service packages have the same core service, but sometimes it is hard to define which the core service is. As for example, a customer cannot pay an invoice without paying the bank service charge. Thus, additional service is built around core service to facilitate customer. It makes the service and interesting and helps to generate more revenue because sometimes it is insignificant to earn revenue only from core services.

\section{Service culture}

However, customer contact at service quality stage on the basis of core service and additional services. At this point, customer becomes very judgmental about the product quality and they create an image quickly whether the service is good or bad. Thus, if contact person does give the right information or become rude every effort goes negatively, and they do not get a second chance to make this positive. Customers' expectation and experience are to be conflicted here. In Figure 1 shows that service quality image is spared in two dimension where customer already hold an image about the experience of owning or some others statements, on the other hand, after experiencing service with company personnel, environment, equipment, etc., if the everything goes positively, customer experience goes overwhelmed, and they do not notice and fault or defect. However, if 
experiences do not meet the expectation then they see all the faults and reinforces.

Service culture is overall atmosphere of service process that gives customers an experience, feel and what they see in company or in organization. It reflects company's values and norms where it is an implied and tacit agreement about what is permitted and forbidden in the service organization (Lahtinen and Isoviita, 1994).

\section{Service quality}

Kasper et al, 2006, defined "service quality as a complex and ephemeral concept which refers to some attribute of what is offered, provided whereas satisfaction or dissatisfaction refers to a customer's reaction to that offer." Zeithaml and Bitner, 2006, refer service quality focuses specifically on dimensions of service. "Service quality is the totality of features and characteristics of service that bear on its ability to satisfy stated or implied needs" (Kotler and Keller, 2009).

Service quality has five principal dimensions that customers use to judge service: Quality - reliability, responsiveness, assurance, empathy, and tangibles (Fitzsimmons and Fitzsimons, 2008). In dimensions of service quality - reliability represents the ability of perform the service both dependably and accurately. It also means service carry out on time, in the same way and without any error every time. Responsiveness refers the ability to respond to customer requirements and to provide prompt service. This ensures to the customer the best service and if any failure occurs, the ability to recover quickly that can create positive perceptions of quality. Assurance is the knowledge, courtesy, confidence, and ability to convey trust of the employees. It includes these features - respect for the customer, politeness, effective communication with the customer. Empathy is the carrying and individual attention to customers including the features of sensitivity, approachability, and understanding customers' needs. Tangibles are the appearance of physical facilities, equipment, and personnel. It has the impact on perceived service quality for instance cleanliness of the service premises (Fitzsimmons and Fitzsimons, 2008).

This dimensions of service quality contain a large part of disconfirmation that derives the perceive service quality. However, the process is influenced by four externalities, word of mouth, personal needs, past experience, and external communications that actually have an impact on the formation of expectations (Kasper et al., 2006). However in the perceived service quality, when the expected service exceeds the perceived service customers become delightful and overwhelmed when the expected service cannot meet; customers become depress and create a negative idea for the service.

\section{E-service: Definitions and characteristics}

There are many definitions of e-services. Some focus on the delivery and delivery infrastructure (digital networks) while others emphasize both the delivery process and the benefits or outcome of the service (Hofacker et al., 2007). However, what is in common to all these definitions are that e-services are characterized by the electronic delivery of the service. Furthermore, an electronic service is a service system (with elements, a structure, a behavior, and a purpose) for which the implementation of many of its elements and behavior is done using automation and programming techniques.

One of the first definitions of e-services was provided by Tiwana and Balasubramaniam in 2001. In this article, they defined e-services in the following manner: We view e-services as internet-based applications that fulfill service needs by seamlessly bringing together distributed, specialized resources to enable complex (often real-time) transactions. Examples of e-services include supply chain management, customer relationship management, accounting, order processing, resource management, and other services that are electronically delivered through the internet.

Thus, E-services constitute a new model for using the Web. It allows the publishing of business functions to the web and enables universal access to these functions.

In addition, according to Scupola (2008), there are three main characteristics of e-services:

- The service is accessible through the internet or other electronic networks

- The service is consumed either directly or indirectly through the internet or other electronic networks

- There might be a fee that the consumer pays the provider for using the e-service (e.g., a surcharge for buying a movie ticket online), but that might not always be the case as is exemplified by some e-services offered by the government.

Much of the theoretical literature on e-services is found within the service and service marketing field and focuses mainly on e-services that are substitutes or complements to offline goods or services. This stream of literature takes mainly a commercial approach to investigating e-services (Hofacker et al., 2007). However, there are many studies investigating e-services that do not have an immediate commercial return but are offered, for example, by government agencies or are e-services provided and coproduced by users such as wikis (Gogia, 2008). 
Therefore, if we take a broader approach to e-services than just service marketing and e-commerce, we can distinguish the following four main groups of e-services:

- Business-to-business (B-to-B): These play an important role in the trend toward supply chain integration and coordination (Iyer et al., 2004), for example, in the case of outsourced printing services and facilities

- Business-to-consumer (B-to-C): These are mostly commercial e-services, for example, e-banking (Toufaily et al., 2009), e-newspapers and some types of portals

- Government to business (G-to-B) or to consumer (G-to-C): These e-services are not commercial in nature and examples can be social security services provided online to remote areas (Rubeck and Miller, 2008), telemedicine or e-libraries

- Consumer-to-consumer (C-to-C): This includes most of the literature on virtual worlds and online communities, for example, wikis and online dating (Krishnan et al., 2003).

\section{Customer Satisfaction}

\section{The concept of customer satisfaction}

Customer satisfaction, as a construct, has been fundamental to marketing for over three decades. As early as 1960, Keith, 1960, defined marketing as "satisfying the needs and desires of the consumer." Several studies have shown that it costs about 5 times to gain a new customer as it does to keep an existing customer, and this leads to more interest in customer relationships. Thus, several companies are adopting customer satisfaction as their operational goal with a carefully designed framework. Hill and Alexander, 2000, wrote in their book that "companies now have big investment in database marketing, relationship management, and customer planning to move closer to their customers." Homburg and Giering, 2001, defined customer satisfaction that is "an experience-based assessment made by the customer of how far his own expectations about the individual characteristics or the overall functionality of the services obtained from the provider have been fulfilled."

Westbrook and Reilly, 1983, defined - customer satisfaction is an as emotional response to the experience provided by (or associated with) particular products or services purchased, retail outlets, or even molar patterns of behavior, as well as the overall marketplace.

Kotler and Keller, 2009, expressed "customer satisfaction is a process of consumer's response to the evaluation of the perceived discrepancy between prior expectations and the actual performance of the product as perceived after its consumption."

Satisfaction is the customer's fulfillment response. It is judgmental that a product or service feature, or the product or service itself, provides a pleasurable level of consumption-related fulfillment (Oliver, 1997). "This definition approaches two sides where the first the approach defines satisfaction as a final situation or as endstate resulting from the consumption experience and the second approach emphasizes the perceptual, evaluative, and psychological process that contributes to satisfaction" (Evangelos and Yannis 2005).

\section{The importance of customer satisfaction}

Customer satisfaction is considered as the baseline of standardize and excellence of performance for many businesses. It also helps to identify potential market opportunities (Evangelos and Yannis, 2010). However, the concept of customer satisfaction is not a new one. It hits the business sectors in the early 1980s where some researchers considered that customer satisfaction is the best window into loyalty. They also found that it has a direct relationship with the company profitability, return on investment, or share of market. Satisfied customer think twice or several times before switching to alternatives because they become attached emotionally and also afraid to believe on alternatives quality (Oliver, 1997).

Zairi, 2000, mention more about the importance as - "numerous studies that have looked at the impact of customer satisfaction repeat purchase, loyalty, and retention. They all bring the similar message. First, satisfied customers share their experience with an average five or six people and dissatisfied customers normally tell ten people about their unfortunate experience. Second, many customers do not complain about dissatisfaction, but it is needs to realize by the company and it differs from industry to industry. After all, people think that managing customer satisfaction is not as expensive as recruiting a new customer. Actually it is only $25 \%$ of the recruit a new customer."

\section{Measuring customer satisfaction}

Today's measuring customer satisfaction becomes an important issue to most of the business organization. If you cannot measure something, you cannot understand it. In recent decades the importance of customer satisfaction has increased; thus, many organizations considered measuring customer satisfaction should be set as a parameter. It also considered as reliable feedback, and it provides as effective, direct, meaningful and objective way the customers' preferences and expectations (Gerson, 1993).

Hill, 1996, said, customer satisfaction measurement provides a sense of achievement and accomplishment for all employees involved in any stage of the customer service process, and it motivates people to perform as well as achieve higher levels of productivity. 
Furthermore, Evangelos and Yannis, 2005, mentioned in their book about the main advantages of measuring customer satisfaction, one-measuring customer satisfaction helps to evaluate a business current position against its competition and accordingly design its future plans. Second satisfaction measurement is able to identify potential market opportunities. Third - it helps to understand customer behavior and particularly to identify and analyze customer expectations, needs, and desire. Fourth - it improves the communication of the total clientele. Fifth by this measurement, it is also possible to examine whether new actions, efforts, and programs have any impact on the organizations' clientele. Sixth - organizations weakness and strength against competition are determined, based on customers' perceptions and judgment. Seventh - personnel is motivated to increase its productivity.

\section{Determinants of customer satisfaction}

Customer satisfaction is one of the most important issues concerning business organizations of all types. Business organizations try to give the best service to the customer and also look for the reason that can increase the satisfaction level. According to Hokanson, 1995, these factors include friendly employees, knowledgeable employees, helpful employees, accuracy of billing, billing timeliness, competitive pricing, service quality, good value, billing clarity, and quick service.

However, Zeithaml and Bitner, 2006, also expressed some determinates that cause customer satisfaction, and they are mentioned as below:

- Product and service features: Customer satisfaction is significantly influenced by the customer's evaluation of product or service features. Thus, firms also study concerning satisfaction what features and attributes of their services customer measure most and that firms measure the perceptions of those features and overall service satisfaction. In this regard, research has found that normally customers make trade-offs among service such as price level versus service quality or friendliness of personnel versus customization (Zeithaml and Bitner, 2006).

- Consumer emotions: Consumer emotions played a significant role in the product or services satisfaction. When a customer is at a happy time in life or in a positive mood that affects the service experience and feels good. Alternatively, when customers passing through bad mood or negative feelings, they might overreact or respond negatively toward the service. It is normally seen that positive emotions had a stronger effect than a negative one. Specific emotions may also be influenced by the consumption experience itself, influencing consumes' satisfaction with the service (Zeithaml and Bitner, 2006).
- Attributions for service success or failure: Attributions are a cause to influence perceptions of satisfaction. Even when customers do not take responsibility for the outcome, customer satisfaction may be influenced by other kinds of attributions. Like sometime customers do not take any consideration of fault made by the personnel if they found it rarely happens, or it is beyond an agent's control (Zeithaml and Bitner, 2006).

- Perceptions of equity and fairness: Perception of equity and fairness has a great impact on customer satisfaction. Customers usually think about whether they treated fairly compare to other customer, was the price eligible for the service, were they get good service. These senses of fairness are central to customer satisfaction, particularly in service recovery situations (Zeithaml and Bitner, 2006).

- Others consumers, family members, and coworker: Customer satisfaction not only depends on the product or service features, one's own experience rather but it also influenced by other customer perception, experiences, etc. As, for example, family members' satisfaction or dissatisfaction influenced tremendously toward particular service - like a vacation trip. Sometimes, friends and families, other member experience stopped thinking of that service (Zeithaml and Bitner, 2006).

\section{Clear understanding of customer needs and expectations}

According to the Kano, 2001, model, customer needs can be divided into:

- Basic needs - obvious needs of customers and if not met, he is dissatisfied, however, meeting this needs may not be enough for customer satisfaction. Its satisfaction results in "must be quality."

- Expected needs - these are important needs that customers are fully aware of and satisfaction is expected in every purchase; their satisfaction creates "expected quality."

- Excitement needs - these are unconscious and unspoken needs of customers. By identifying and satisfying such needs, companies will have added large value to customers and can win loyal customers. This satisfaction creates "attractive quality."

\section{Customer loyalty and retention}

Customer loyalty means sticking with a supplier who treats him well and gives him good value in the long term even if the supplier does not offer the best price in a particular transaction (Lovelock and Wirtz, 2007). They also mention in their book that customer loyalty is much more than repeat purchases. They might not buy products frequently, but they drive business top-line growth. Loyal customer's recommendation to their friend, family, and 
colleagues indicate that business gives the best economic value of the product or service. Moreover, loyal customer indirectly increases the number of new customer - at no charge to the company which, on the other hand, increases company's growth.

Sivadass and Baker-Prewitt, 2000, stated, "the ultimate objective of the customer satisfaction measurement should be customer loyalty. Actually satisfaction fosters loyalty to the extent that is prerequisite for maintaining a favorable relative attitude and for recommending and repurchasing from the supplier."

Only customer satisfaction is not enough in today's business perspective rather there has to be an extremely satisfied customer, because it leads to customer loyalty. Some author also mention that building customer loyalty is not a choice for business, but it is the only way of building sustainable competitive advantage. Although there is no definite rule to create customer loyalty study showed these following aspects might help to build that, first focus on key customers, second - generating a high level of customer satisfaction with every interaction proactively, third understand customer needs and demand, then respond to them before the competition does, fourth - develop closer ties with customers, and finally create a value perception (Bansal and Gupta, 2001).

Customer satisfaction is an antecedent of customer retention (Athanassopoulos, 2000); customer satisfaction is a central determinant of customer retention (Gerpott et al., 2001); and customer satisfaction is positively related to customer retention and the effect varies by customer size and the customer's current level of satisfaction (Niraj et al., 2003).

\section{MATERIALS AND METHODS}

To investigate the objectives of this study and answer the research questions, the descriptive research method was employed. The questionnaire survey technique was used to collect data, and the questions were self-constructed. In this research, customer satisfaction was surveyed in Erbil city of the Kurdistan Region. The data were collected from 400 customers who were randomly selected for the year 2017, by the use of a questionnaire survey. The questions for this survey included questions on personal background, age (lowest range was $<25$ and highest was more than $30)$, gender, employment type, employment (public, nonpublic), education level (illiterate, secondary education, diploma, and higher education), marital status, with other questions about income, expenditure on internet services, and expenditure on internet combined with mobile phone services.
Other questions were on variables: Use of internet service performance network quality/availability, billing, speed, and customer care services.

The questionnaire employed the typical form of fixed-response alternative questions that require the respondent to select from a predetermined set of answers to every question. According to Malhotra and Birks, 2003, this survey approach is the most common method of primary data collection in marketing research, and the advantages are simple administration and data consistency.

The questionnaires employed the Likert non-comparative scaling technique. It is a widely used rating scale which requires the respondents to indicate a degree of agreement or disagreement with each of a series of statements or questions. This rating scale is easy to construct and administer and respondents readily understand how to use the scale (Malhotra and Birks, 2003).

\section{RESULTS AND DISCUSSION}

Table (1) represents the sociodemographic and economic characteristics of customer satisfaction in the study. According to the field survey of respondents, $57 \%$ were male, $40.0 \%$ were in the $25-30$ age groups, and $55.0 \%$ had university education. The study revealed that the largest proportion of respondents, $52.5 \%$, was single.

\begin{tabular}{|c|c|}
\hline Variables & Frequency (\%) \\
\hline \multicolumn{2}{|l|}{ Age group } \\
\hline$<25$ & $131(32.8)$ \\
\hline $25-30$ & $160(40.0)$ \\
\hline$>30$ & $109(27.2)$ \\
\hline Total & $400(100.0)$ \\
\hline \multicolumn{2}{|l|}{ Gender } \\
\hline Male & $228(57.0)$ \\
\hline Female & $172(43.0)$ \\
\hline Total & $400(100.0)$ \\
\hline \multicolumn{2}{|l|}{ Marital-status } \\
\hline Married & $188(47.0)$ \\
\hline Single & $212(53.0)$ \\
\hline Total & $400(100.0)$ \\
\hline \multicolumn{2}{|l|}{ Education level } \\
\hline Illiterate-high school & $55(13.8)$ \\
\hline Diploma & $125(31.2)$ \\
\hline University & $220(55.0)$ \\
\hline Total & $400(100.0)$ \\
\hline \multicolumn{2}{|l|}{ Type of employment } \\
\hline Public employment & $251(62.8)$ \\
\hline Self-employment & $149(37.2)$ \\
\hline Total & $400(100.0)$ \\
\hline
\end{tabular}


According to the survey, about $62.8 \%$ of the respondents are in public employment. This result concludes that most of the customers are young people who are still strong and full of energy to use and gain information through technology.

In Table (2), the dependent variable (customer satisfaction) was analyzed with the descriptive statistics (frequency distribution). This result demonstrates that $81.5 \%$ of the respondents are satisfied and with $18.5 \%$ not being satisfied with the internet services in Erbil. The interpretation of this result could be that Kurdish customers are satisfied with the internet service performance.

Table (3) shows that many of the respondents $(80.2 \%)$ did not use a home phone, with $19.8 \%$ of the respondents using a home phone. According to this table, respondents $(93.5 \%)$ did not have a home phone with internet services subscription, but $6.5 \%$ of respondents had a home phone with an internet subscription. Most of the respondents $(83 \%)$ have a subscription to the internet by mobile phone compared with $19.8 \%$ of respondents having a subscription through a computer. This study suggests that customer's subscription by mobile phone is greater than subscription with computer.

Table (4) illustrates that the majority of customers (62.5\%) were somewhat satisfied; also, $24.5 \%$ of respondents

$\begin{aligned} & \text { Table 2: The result of the analyzed overall customer } \\
& \text { satisfaction }\end{aligned}$
\begin{tabular}{lc}
\hline Variables overall customer satisfaction & Frequency (\%) \\
\hline Not satisfied & $74(18.5)$ \\
Satisfied & $326(81.5)$ \\
Total & $400(100.0)$ \\
\hline
\end{tabular}

Table 3: Method of subscription to the internet services by customers

\begin{tabular}{lc}
\hline Variables & Frequency (\%) \\
\hline Use home phone & \\
Yes & $79(19.8)$ \\
No & $321(80.2)$ \\
Total & $400(100.0)$ \\
Home phone subscription & \\
Yes & $26(6.5)$ \\
No & $374(93.5)$ \\
Total & $400(100.0)$ \\
Mobile phone subscription & \\
Yes & $332(83.0)$ \\
No & $68(17.0)$ \\
Total & $400(100.0)$ \\
Computer subscription & \\
Yes & $79(19.8)$ \\
No & $321(80.2)$ \\
Total & $400(100.0)$ \\
\hline
\end{tabular}

were not at all satisfied and $13.0 \%$ respondents were very satisfied in network availability. Regarding the costs of internet services, the majority of respondents $55.0 \%$ were not at all satisfied; $34.2 \%$ of respondents were somewhat satisfied; and $10.8 \%$ of respondents were very satisfied. Another field is the speed of service, $51.8 \%$ of respondents were somewhat satisfied, and $37.0 \%$ of respondents were not at all satisfied, with $11.2 \%$ of respondents being very satisfied. About $62.3 \%$ of respondents were somewhat satisfied, $28.2 \%$ of respondents were not at all satisfied, and $9.5 \%$ of respondents were very satisfied in overall customer care service. About $58.3 \%$ of respondents were somewhat satisfied, also $30.2 \%$ not at all satisfied and $11.5 \%$ are very satisfied about variable ability to get attendant quickly. Furthermore, there were a great number of the respondents, $62.8 \%$ somewhat satisfied, $27.7 \%$ not at all satisfied, and 9.5 were very satisfied of variable ability to provide a solution.

The sample characteristics in the usage of the internet services are summarized in Table (5). It shows the distribution of internet subscribers. It is noted that FAST link, Tarin net, Korek telecom and, among others Soran net,

Table 4: Customer satisfaction on internet services variables

\begin{tabular}{lc}
\hline Variables & Frequency (\%) \\
\hline Network availability & \\
Not at all satisfied & $98(24.5)$ \\
Somewhat satisfied & $250(62.5)$ \\
Very satisfied & $52(13.0)$ \\
Total & $400(100.0)$ \\
Billing & \\
Not at all satisfied & $220(55.0)$ \\
Somewhat satisfied & $137(34.2)$ \\
Very satisfied & $43(10.8)$ \\
Total & $400(100.0)$ \\
Speed & \\
Not at all satisfied & $148(37.0)$ \\
Somewhat satisfied & $207(51.8)$ \\
Very satisfied & $45(11.2)$ \\
Total & $400(100.0)$ \\
Overall customer care service & \\
Not at all satisfied & $113(28.2)$ \\
Somewhat satisfied & $249(62.3)$ \\
Very satisfied & $38(9.5)$ \\
Total & $400(100.0)$ \\
Ability to get attendant quickly & \\
Not at all satisfied & \\
Somewhat satisfied & $121(30.2)$ \\
Very satisfied & $233(58.3)$ \\
Total & $46(11.5)$ \\
Not at all satisfied & $400(100.0)$ \\
Ability to provide a solution & $111(27.7)$ \\
Very satisfied & \\
Total & $251(62.8)$ \\
\hline & $400(100.0)$ \\
\hline
\end{tabular}


Reber, Zine, ADSL, Tishk net, Asia cell comprise 34.3\%, $17.5 \%, 16.5 \%$, and $11.5 \%, 7.8 \%, 5.8 \%, 5.0 \%, 1.3 \%$, and $1.0 \%$ of the respondents' subscriptions.

Table (6) shows the mean values of age, income, costs of internet services and costs of both internet services amalgamated with mobile phone services in Erbil. With regard to the age demographic in the study area, 28.18\% of respondents' monthly income was ID 592,100.00, average expenses for internet services for each month were respondents ID 30,125.00, and average expenses for charging of internet service and mobile phone for each month were ID 54,493.75.

After a more detailed analysis of customer satisfaction for the income group, we can identify three groups, as shown in Table (7):

The first income group earns less than IQD 500,000, the second income group earns between IQD 500,000 and 700,000 , and third income group earn more than IQD 700,000 . In other words, in the first income group, the average was IQD 408,680.37, the customers' average expenditure on internet services was IQD 27,555.94, and the average expenditure for internet and phone calls was IQD 52,105.02. The average income between IQD

Table 5: Distribution of internet subscribers

\begin{tabular}{lc}
\hline Variables brand & Frequency (\%) \\
\hline Fast link & $137(34.3)$ \\
Tarin net & $70(17.5)$ \\
Korek tell & $66(16.5)$ \\
Soran net & $44(11.0)$ \\
Reber & $31(7.8)$ \\
Zine & $23(5.8)$ \\
ADSL & $20(5.0)$ \\
Tishk net & $5(1.3)$ \\
Asia cell & $4(1.0)$ \\
Total & $400(100.0)$ \\
\hline
\end{tabular}

ADSL: Name of the internet service provider company

Table 6: Mean values of age, income, costs of internet services, and costs of both internet and mobile service

\begin{tabular}{lcccc} 
Variables & Age & Income & $\begin{array}{c}\text { Costs of } \\
\text { internet }\end{array}$ & $\begin{array}{c}\text { Costs of } \\
\text { internet and } \\
\text { mobile phone }\end{array}$ \\
\hline Mean & $28.18 \%$ & $592,100.00$ & $30,125.00$ & $54,943.75$ \\
SD & 6.344 & $392,132.912$ & $17,359.461$ & $30,592.498$ \\
\hline
\end{tabular}

SD: Standard deviation
500,000 and 700,000 is IQD 617,153.15; in this income group customers have been paying IQD 29,461.71 for internet services and IQD 51,851.35 for both of them. In addition, the average expenditure for internet services was IQD 39,214.29 and IQD 68,728.57 for internet services and phone calls, while customers' average income was IQD $1,126,214.29$ in the third income group.

In the analyzed percentage expenditure of the internet services, we notice that $6.74 \%$ of the first average income, $4.77 \%$ in the second group, and $3.48 \%$ in the last group were customer costs for internet services per month. The customer has been charged for the internet service and mobile phone calls by $12.75 \%, 8.40 \%$, and $6.10 \%$.

To explore the relationship between demographic variables and customer satisfaction, the Chi-square test was applied. Table (8) represents the result of the relationship between demographic variables and customer satisfaction.

This result demonstrates that there is a relationship between gender and customer satisfaction; the interpretation of the result is that gender has a significant impact on customer perception of how well the internet services meet the requirements and expectations. The result shows that there is no relationship between age group, maritalstatues, education, job, income group, expenditure of internet group and expenditure of internet and mobile phone group, and customer satisfaction. Therefore, this means that all of the demographic variables have an insignificant impact on how customers evaluate service performance. This result could also be due to the fact that the internet industry is still growing and/or it is too early to establish such relationships because the study is new to Kurdish customers. The results also indicate that there is a relationship between network availability, billing, speed, overall customer care service, ability to receive timely attention, and ability to provide a resolution and customer satisfaction. The implication of this result is that network availability, billing, speed, overall customer care service, and ability to get speedy attention and the ability to provide a solution to the internet services is the most significant of all the internet service attributes in Erbil. The results, therefore, mean that the customer's perception of all the above variables strongly affects their perception of internet operators and their satisfaction level.

Table 7: Income groups and their average monthly expenses of internet services

\begin{tabular}{lcccccc} 
Income group ID & $\boldsymbol{n}$ & Average income ID & $\begin{array}{c}\text { Average expenses } \\
\text { of internet ID }\end{array}$ & $\begin{array}{c}\text { Average expenses of } \\
\text { internet and phone ID }\end{array}$ & $\begin{array}{c}\text { Expenses of } \\
\text { internet (\%) }\end{array}$ & $\begin{array}{c}\text { Expenses of internet } \\
\text { and phone (\%) }\end{array}$ \\
\hline$>500,000$ & 219 & $408,680.37$ & $27,555.94$ & $52,105.02$ & 6.74 & 12.75 \\
$500,000-700,000$ & 111 & $617,153.15$ & $29,461.71$ & $51,851.35$ & 4.77 & 8.40 \\
$<700,000$ & 70 & $1,126,214.29$ & $39,214.29$ & $68,728.57$ & 3.48 & 6.10 \\
\hline
\end{tabular}


Table 8: Relationship between demographic variables and customer satisfaction

\begin{tabular}{|c|c|c|c|}
\hline \multirow[t]{2}{*}{ Variables } & \multicolumn{2}{|c|}{ Overall satisfaction } & \multirow[t]{2}{*}{ Chi-square test $(P)$} \\
\hline & Not satisfied & Satisfied & \\
\hline \multicolumn{4}{|l|}{ Gender } \\
\hline Male & 56 & 173 & $12.595(0.000)$ \\
\hline Female & 18 & 153 & \\
\hline \multicolumn{4}{|l|}{ Age group } \\
\hline$>25$ & 23 & 108 & $0.126(0.939)$ \\
\hline $25-30$ & 30 & 130 & \\
\hline$<30$ & 21 & 88 & \\
\hline \multicolumn{4}{|l|}{ Marital-statues } \\
\hline Married & 35 & 153 & $0.003(0.955)$ \\
\hline Single & 39 & 173 & \\
\hline Illiterate-high school & 12 & 43 & \\
\hline \multicolumn{4}{|l|}{ Education } \\
\hline Diploma & 19 & 106 & $1.464(0.481)$ \\
\hline University & 43 & 177 & \\
\hline \multicolumn{4}{|l|}{ Job } \\
\hline Public employment & 51 & 200 & $1.478(0.224)$ \\
\hline Self-employment & 23 & 126 & \\
\hline \multicolumn{4}{|l|}{ Income group } \\
\hline$>500,000$ & 48 & 171 & $3.750(0.153)$ \\
\hline $500,000-700,000$ & 16 & 95 & \\
\hline$<700,000$ & 10 & 60 & \\
\hline \multicolumn{4}{|c|}{ Expenses of internet group } \\
\hline$>25,000$ & 35 & 146 & $0.821(0.663)$ \\
\hline $25,00-35,000$ & 23 & 93 & \\
\hline$<35,000$ & 16 & 87 & \\
\hline \multicolumn{4}{|c|}{ Expenses of internet phone call group } \\
\hline$>40,000$ & 24 & 133 & $1.790(0.409)$ \\
\hline $40,000-55,000$ & 21 & 79 & \\
\hline$<55,000$ & 29 & 114 & \\
\hline \multicolumn{4}{|l|}{ Network availability } \\
\hline Not at all satisfied & 48 & 50 & $80.923(0.000)$ \\
\hline Somewhat satisfied & 24 & 226 & \\
\hline Very satisfied & 2 & 50 & \\
\hline \multicolumn{4}{|l|}{ Billing } \\
\hline Not at all satisfied & 61 & 159 & $27.770(0.000)$ \\
\hline Somewhat satisfied & 9 & 128 & \\
\hline Very satisfied & 4 & 39 & \\
\hline \multicolumn{4}{|l|}{ Speed } \\
\hline Not at all satisfied & 54 & 94 & $50.849(0.000)$ \\
\hline Somewhat satisfied & 18 & 189 & \\
\hline Very satisfied & 2 & 43 & \\
\hline \multicolumn{4}{|c|}{ Overall customer care service } \\
\hline Not at all satisfied & 53 & 60 & $84.387(0.000)$ \\
\hline Somewhat satisfied & 19 & 230 & \\
\hline Very satisfied & 2 & 36 & \\
\hline \multicolumn{4}{|c|}{ Ability to get quickly attendant } \\
\hline Not at all satisfied & 46 & 75 & $43.850(0.000)$ \\
\hline Somewhat satisfied & 23 & 210 & \\
\hline Very satisfied & 5 & 41 & \\
\hline \multicolumn{4}{|c|}{ Ability to provide a solution } \\
\hline Not at all satisfied & 48 & 63 & $63.722(0.000)$ \\
\hline Somewhat satisfied & 20 & 231 & \\
\hline Very satisfied & 6 & 32 & \\
\hline
\end{tabular}




\section{CONCLUSION}

This study aimed to investigate customer satisfaction with the internet services industry, factors influencing satisfaction and the relationship between demographic variables and customer satisfaction in Erbil, Iraqi Kurdistan. Customer satisfaction is an experience-based assessment made by customers about how far their expectations of the overall functionality of the services obtained from the internet operators have been fulfilled. With regard to customer satisfaction measurement, the results demonstrated that customers are satisfied with the performance of the Erbil internet services industry. The interpretation of this result could be that Erbil customers are actually satisfied with the service performance or that their satisfaction results from a lack of competing services; it could be that customers are new to satisfaction measurement and may not be able to express their perceptions accurately. The result also demonstrated that customer satisfaction level differs among specific demographic groups. Within the age groups, the younger customers were more satisfied than the older age group or teenagers. The lower satisfaction of the old and teenage customers could be due to greater familiarity with internet technology and they are therefore more demanding. Male customers showed greater satisfaction than their female counterparts. The higher satisfaction of male customers could be due to the impact of services on their functional activities. Public employees demonstrated more satisfaction than the self-employed and the higher satisfaction of public employees could be due to actual satisfaction, or a lower knowledge of internet technology. Finally, those on a lower income demonstrated more satisfaction than those on a higher income. The lower satisfaction of high-income customers is maybe due to a greater familiarity with information technology, and therefore, they are more demanding. However, internet operators need to strive to maximize customer satisfaction which, in turn, can influence the extent of loyalty and retention.

\section{RECOMMENDATIONS}

Based on the above conclusions, and supplementing the requirements of the study, this section presents a number of recommendations and proposals that the researchers deems appropriate to enhance the levels of availability of the customer satisfaction in the investigated internet service companies and to increase their ability to adopt with the external environment to compete with developed countries, as follows:

1. The senior management team in the companies concerned should seek to develop the smart leadership index by developing the leadership skills of the team members through theoretical and field training, as well as reviewing the structure of the senior management team and adapting it to the new opportunities in the work environment. Especially when foreign companies compete with them in the fields related to customer satisfaction.

2. Give special importance to continuous learning by guiding the potential of the research organizations and their resources, and encouraging the employees to learn continuously, and make the changes required to achieve this. Follow-up senior management of continuing education processes on a regular basis about new ways of giving services and customer satisfaction.

3. The investigated organizations conduct a survey of environmental factors, their follow-up and understanding of the surrounding environment and their variables to reduce environmental uncertainties and knowing their customers' needs and desires.

4. The need for an administrative unit in the companies investigated under the title: "Customer support," concerned with collecting data related to studying the work environment and then addressing them to serve those customers because its the key for customer loyalty toward company.

\section{REFERENCES}

Athanassopoulos, A. D. 2000. Customer satisfaction cues to support market segmentation and explain switching behavior. J. Bus. Res. 47(3): 191-207.

Bansal, S. and G. Gupta. 2001. Building Customer Loyalty Businessto-Business Commerce. Tata McGraw-Hill, New Delhi.

Cook, S. 2002. Customer Care Excellence. Kogan Page Limited, London.

Deng, Z., Y. Lu, K. K. Wei and J. Zhang. 2009. Understanding customer satisfaction and loyalty: An empirical study of mobile instant messages in China. Int. J. Inf. Manage. 30: 289-300.

Eshghi, A., D. Haughton and H. Topi. 2007. Determinants of customer loyalty in the wireless telecommunications industry. Telecomm. Policy 31(2): 93-106.

Evangelos, G. and S. Yannis. 2005. Customer Satisfaction Evaluation: Methods for Measuring and Implementing Service Quality. Springer, London.

Fitzsimmons, J. and M. Fitzsimmons. 2008. Service Management. Mc Graw-Hill, Inc., New York.

Gerpott, T. J., W. Rams and A. Schindler. 2001. Customer retention, loyalty, and satisfaction in the German mobile telecommunications market. Telecomm. Policy 25(4): 249-269.

Gerson, R. F. 1993. Measuring Customer Satisfaction. Crisp Publication, Inc., Menlo Park, California.

Gogia, S. B. 2008. Providing Tele mental health services after disasters a case based on the post tsunami experience. In: Scupola, A., editor. Cases on Managing E-services. Idea Group Inc., USA.

Gustafsson, A., M. D. Johnson and I. Roos. 2005. The effects of customer satisfaction, relationship commitment dimensions, and triggers on customer retention. J. Market. 69: 210-218. 
Hennig-Thurau, T. and A. Klee. 1997. The impact of customer satisfaction and relationship quality on customer retention: $A$ critical reassessment and model development. Psychol. Market. 14(8): 737-764.

Hill, N. 1996. Handbook of Customer Satisfaction Measurement. Resource Center for Customer Service Professionals, Western Springs, IL.

Hill, N. and J. Alexander. 2000. Handbook of Customer Satisfaction and Loyalty Measurement. $2^{\text {nd }}$ ed. Gower Publishing Ltd., England.

Hofacker, C. F., R. E. Goldsmith, E. Bridges and E. Swilley. 2007. E-Services: A synthesis and research Agenda. J. Value Chain Manage. 1(1/2): 13-44.

Hokanson, S. 1995. The Deeper you Analyze, the More you Satisfy Customers. Marketing News. p16.

Homburg, C. and A. Giering. 2001. Personal characteristics as moderators of the relationship between customer satisfaction and loyalty an empirical analysis. Psychol. Market. 18(1): 43-66.

lyer, K. N. S., R. Germain and G. L. Frankwick. 2004. Supply chain B2B E-commerce and time-based delivery performance. Int. J. Phys. Distrib. Logist. Manage. 34(8): 645-661.

Jalulah, S.P., M. M. Wandaogou and Abdil. 2011. Evaluation of Customer Satisfaction with Internet Banking Service Quality in the banking Industry in Ghana, Master's Thesis, Luleå University of Technology. p1-124.

Janda, S., P. J. Trocchia and K. P. Gwinner. 2002. Consumer perceptions of internet retail service quality. Int. J. Serv. Ind. Manage. 13(5): 412-431.

Ju, H., R. Yen and K. P. Gwinner. 2016. Internet retail customer loyalty: The mediating role of relational benefits. Int. J. Serv. Ind. Manage. 14(5): 483-500.

Kano, N. 2001. Life cycle and creation of attractive quality. In: Dahlgaard, S.M., editor. Proceeding from Quality Management and Organization Development (QMOD). Linkoping University, Sweden.

Kasper, H., P. Helsdingen and M. Gabbott. 2006. Service Marketing Management. John Wiley and Sons, Ltd., West Sussex.

Keith, R. J. 1960. The marketing revolution. J. Market. 24: 35-38.

Khalifa, M. and V. Liu. 2016. Satisfaction with Internet-Based Services : The Role of Expectations and Desires. Int. J. Electron. Commer. 7(2): 31-49.

Khayyat, N. T. and A. Heshmati. 2012. Determinants of mobile phone customer satisfaction in the Kurdistan Region. J. Knowl. Manage. Econ. Inf. Technol. 2(3): 91-121.

Kim, M. K., M. C. Park and D. H. Jeong. 2004. The effects of customer satisfaction and switching barrier on customer loyalty in Korean mobile telecommunication services. Telecomm. Policy 28(2): 145-159.

Kotler, P. and K. Keller. 2009. Marketing Management. Person Education, New Jersey.
Krishnan, R., M. D. Smith and R. Telang. 2003. The economics of peer-to-peer networks. J. Inf. Technol. Theory 5(3): 31-44.

Lahtinen, J. and A. Isoviita. 1994. Customer Relationship Marketing. KP Paino, Kokkola, Avaintulos, OY. Tampere, Finland.

Lovelock, C. and J. Wirtz. 2007. Services Marketing. Prentice Hall, New York.

Malhotra, N. and D. Birks. 2003. Marketing Research, An Applied Approach. Prentice Hall, Harlow, England.

Niraj, R., G. Foster, M. Gupta and C. Narasimhan. 2003. Understanding Customer Level Profitability Implications of Satisfaction Programs. Washington University in St Louis. Working Paper, No. 2003-09-001. Olin School of Business, St Louis, MO.

Oliver, R. L. 1997. Satisfaction: A Behavioural Perspective on the Consumer. Irwin/McGraw-Hill, New York.

Oliver, R. L. 1999. Whence consumer loyalty. J. Market. Fundam. Issues Dir. Market. 63: 33-44.

Roy, P. S. 2013. Wireless internet service and customer satisfaction: A case study on young generation in Bangladesh. Asian J. Appil. Sci. Eng. 2(2): 96-102.

Rubeck, R. and G. A. Miller. 2008. Cases on managing E-services. In: Scupola, A., editor. vGOV! Remote Video Access to Government Services. Idea Group Inc., USA.

Sanchez-franco, M. J., F. A. Martín-Velicia and Á. F. Villarejo-Ramos. 2009. The moderating effect of gender on relationship quality and loyalty toward Internet service providers. Inf. Manage. 46: 196-202.

Scupola, A., editor. 2008. Cases on Managing E-Services. Idea Group Inc., USA.

Sivadass, E. and J. Baker-Prewitt. 2000. An examination of the relationship between service quality, customer satisfaction, and store loyalty. Int. J. Retail Distrib. Manage. 28(2): 73-82.

Tiwana, A. and R. Balasubramaniam. 2001. E-services, Problems, Opportunities, and Digital Platforms. $34^{\text {th }}$ Hawaii International Conference on System Sciences.

Toufaily, E., N. Daghfous and R. Toffoli. 2009. The adoption of "E-banking" by Lebanese banks: Success and critical factors. Int. J. Serv. Mob. Appl. 1(1): 67-93.

Turel, O. and A. Serenko. 2006. Satisfaction with mobile services in Canada: An empirical investigation. Telecomm. Policy 30(1): 314-331.

Westbrook, R. and M. D. Reilly. 1983. Value-percept disparity: An alternative to the disconfirmation of expectations theory of consumer satisfaction. In: Bagozzi, R. P. and A. M. Tybout., editors. Advances in Consumer Research. Association for Consumer Research, Ann Arbor, MI. p256-61.

Zairi, M. 2000. Managing customer dissatisfaction through effective, complaint management systems. TQM Mag. 12(5): 331-335.

Zeithaml, V. and M. Bitner. 2006. Services Marketing. McGraw-Hill, New York. 


\section{QUESTIONNAIRE TEMPLATE}

1. Do you use the internet services?

[] YES [] NO

2. If YES, which of the kind of services do you use? 1-ADSL[] 2-Fast link [] 3-Tarin net[ ]

4-Soran net[] 5-Korek tel [] 6-Asia cell []

7-Zain 8-Rebar [] 9-Tishk net []

3. Please indicate your gender.

Male [] Female []

4. Please what is your age?

[]

5. Please indicate your marital status.

[] married [] single [] other, please specify

6. What is your highest academic or professional qualification?

Illiterate [] high-school [] Diploma []

Bachelor's degree []

Postgraduate/Master's degree [ ] PhD [ ]

7. Which of the following indicate your type of employment?

Public employment [] $\quad$ private employment [] Self-employment [] student [] unemployment []

8. What is your monthly income? []

9. How much are you pay for internet services monthly? []

10. How much are you expenditure for cell phone and internet services monthly?
11. Do you have a home telephone?

[]YES [] NO

12. If, yes is your home telephone subscription with internet?

[] YES [] NO

13. Is your mobile phone subscription with internet? [] YES [] NO

14. Is your computer subscription with internet? [] YES [] NO

15. Please rate your satisfaction of this service on the following

\begin{tabular}{llll}
\hline Details & $\begin{array}{l}\text { Not at all } \\
\text { satisfied }\end{array}$ & $\begin{array}{l}\text { Somewhat } \\
\text { Satisfied }\end{array}$ & $\begin{array}{l}\text { Very } \\
\text { satisfied }\end{array}$ \\
\hline $\begin{array}{l}\text { Network availability } \\
\text { Billing }\end{array}$ & & & \\
Speed & & & \\
\hline
\end{tabular}

16. Which you call to complain anything, how satisfied are you on the following:

\begin{tabular}{llll}
\hline Details & $\begin{array}{l}\text { Not at all } \\
\text { satisfied }\end{array}$ & $\begin{array}{l}\text { Somewhat } \\
\text { Satisfied }\end{array}$ & $\begin{array}{l}\text { Very } \\
\text { satisfied }\end{array}$ \\
\hline Overall customer care service & & & \\
Ability to get attendant quickly & & \\
Attitude of the attendant & & \\
Ability to provide a solution & \\
\hline
\end{tabular}

17. Overall, how satisfied are you with the use of this service?

Not at all satisfied [] $\quad$ somewhat satisfied [ ] very satisfied [] 